\title{
Self-Regulated Learning in Undergraduate Science
}

\author{
Nathan L. Higgins ${ }^{\mathrm{a}}$, Sarah Frankland ${ }^{\mathrm{b}}$, Joseph A. Rathner ${ }^{\mathrm{a}}$ \\ Corresponding author: Joseph A. Rathner, joseph.rathner@unimelb.edu.au \\ ${ }^{a}$ Faculty of Medicine, Dentistry and Health Sciences, University of Melbourne, Victoria, 3010, Australia \\ ${ }^{\mathrm{b}}$ Faculty of Veterinary and Agricultural Sciences, University of Melbourne, Victoria, 3010, Australia
}

Keywords: self-regulated learning, performance, metacognition, motivation, science

\begin{abstract}
Undergraduate science courses are particularly challenging for students transitioning into university. The departure from supportive high school environments can be difficult for students lacking self-directed and selfmotivated learning skills. Many high-achieving school graduates entering higher education are surprised to discover they are ill-prepared to be accountable for their learning (Stanton et al., 2015). Over the past two decades, there has been a mounting interest in the pedagogical approaches aimed at equipping students with the capabilities of a lifelong learner (Australian Qualifications Framework, 2013; Oliver \& Jorre de St Jorre, 2018; Boud \& Dochy, 2010). Consequently, research efforts in higher education have attempted to identify the behavioural strategies and motivational states associated with academic success. Self-regulated learning (SRL) is an umbrella term encompassing the independent and self-directed strategies that allow students to recognise and regulate their learning (Dinsmore et al., 2008). In brief, self-regulation is what a lifelong learner does. In science disciplines, much attention has been directed towards curricula that facilitate the development of SRL in students, such that they become aware of, and maintain control over their learning of complex scientific concepts. This study reviews the current theoretical perspectives, methodological approaches, and emerging trends from research on SRL in higher education science.
\end{abstract}

\section{Introduction}

\section{What is Self-Regulated Learning?}

A universal and comprehensive definition of SRL has been elusive in the literature (Dinsmore, Alexander, \& Loughlin, 2008). Self-regulation is a composite concept, allowing for interrelationships between key learning constructs to be considered within a single framework rather than exploring these areas in isolation. Zimmerman (2001) suggests that self-regulatory processes, such as goal-directed thoughts, feelings, and behaviours, allow the learner to transform their cognitive abilities into task-related academic skills. It remains contested in the literature whether self-regulation is an innate or acquired (teachable) skill, nevertheless even students with significant motivational, neurological, or behavioural disadvantages are thought to be capable of recognising their own learning weaknesses and implementing strategies to overcome them (Ruban, McCoach, McGuire, \& Reis, 2003). From this perspective, all students are thought to self-regulate to some extent. Evidence suggests that the more a student engages in SRL, the higher the quality and quantity of their SRL strategies (Cohen, 2012).

Models of SRL document the self-directed strategies that students use in each stage of the learning process. There are three main process-orientated models of SRL that relate to learning in higher education (Pintrich, 2000; Winne \& Hadwin, 1998; Zimmerman, 2000). Each of these models is unique in the conceptual framing of SRL, and is influenced by underlying theoretical perspectives about the learning process more generally (Panadero, 2017; Puustinen \& Pulkkinen, 2001). For example, the models of Zimmerman and Pintrich are heavily informed by Social Cognitive Theory, which focuses on the separate but interdependent contributions of 
personal, behavioural, and environmental factors (Bandura, 1986). Winne and Hadwin's model is informed by Information Processing Theory, conceiving SRL in terms of (1) how the information is being processed, (2) what information is being processed, and (3) internal feedback mechanisms (Miller, Galanter, \& Pribram, 1960). All three models frame SRL in cyclical 'phases' of learning, whereby each phase comprises a set of strategies that a student uses in the completion of a task. The SRL strategies included in each learning phase are thought to depend on how the authors of each model approach five common underlying issues related to learning (Zimmerman, 2001):

1. What motivates students to self-regulate during learning?

2. Through what process or procedure do students become self-reactive or self-aware?

3. What are the key processes or responses that self-regulated students use to attain their academic goals?

4. How do the social and physical environment affect student self-regulated learning?

5. How does a learner acquire the capacity to self-regulate when learning?

\section{Measuring Self-Regulated Learning}

Process-oriented models of SRL have been essential to the design of instruments used in SRL measurement. Establishing relationships between SRL and academic performance depends on the availability of valid and reliable instruments that measure SRL in students. Self-report instruments, such as questionnaires and surveys, comprised the first-wave of SRL measurement. These typically ask students to reflect on various aspects of their learning, such that students themselves classify or deduce their own activities (Schellings \& Van HoutWolters, 2011). Pintrich's (1990) 'Motivated Strategy for Learning Questionnaire' (MSLQ) was one of the first tools used in SRL research, and remains the most popular and widely used self-report instrument. (Pintrich \& De Groot, 1990; Roth, Ogrin, \& Schmitz, 2016). The MSLQ asks students to report their use of a number of learning strategies (e.g., time-management, goal-setting), as well as the beliefs, expectations and motivations that drive SRL. In addition to their utility in measuring SRL in students, self-reporting has proved to be effective in making students more aware of their level of self-regulatory competence. In so doing, self-reports are thought to promote the development of deep learning strategies in students, in addition to their primary function as SRL measurement tools (Schellings \& Van Hout-Wolters, 2011).

Despite the advantages associated with the self-report method, some researchers have advocated for new methods of SRL testing (Winne \& Perry, 2012). Self-reports treat SRL as a stable trait or enduring aptitude of the student, representing a typical approach to learning consistent over time and across learning contexts. As motivation and strategy-use commonly fluctuate over the course of learning, a student's self-reported SRL assessment may vary depending on when they are assessed. Self-reports also rely on the accurate recollection of strategies used in past learning, as well as a clear understanding of the precise learning context from which to draw that information. One review of self-report studies found significant discrepancies between students' reported SRL and observations of their actual behaviour (Rovers, Clarebout, Savelberg, de Bruin, \& van Merriënboer, 2019). As an alternative to selfreports, instruments that measure SRL in real-time have been designed to circumvent perception-based biases and moment-to-moment fluctuations. These 'behavioural' assessment tools seek to objectively capture a snapshot of students' SRL at a specific point in time, and in a specific learning context, thereby treating SRL as an 'event' as opposed to an enduring 'aptitude' (Winne \& Perry, 2012). For example, 'think-aloud protocols' have students verbalise their cognitive operations during a task, allowing researchers to observe instances of SRL as they occur. While this may constitute a more accurate method of SRL assessment (Winne \& 
Perry, 2012), the observation and coding of real-time SRL is particularly difficult during complex learning tasks in higher education. In fact, it has been argued that behavioural assessments in higher education are neither practicable nor easily interpretable outside a laboratory environment (Roth et al., 2015). Ultimately, Dinsmore et al. (2008) conclude that neither self-reports nor behavioural assessments will suffice to reveal SRL, but that some combination of both may be required. Thus, taking a mixed methods approach may allow the strengths of each method to be used to obtain a broad picture of students' learning strategies.

\section{Trends in Self-Regulated Learning}

A focus of research on SRL in higher education has been on the relationship between specific SRL strategies and academic success. However, dealing with the broader question of "Does SRL improve performance?" has proved challenging. Disentangling each empirical contribution according to both SRL model and measurement protocol would be extremely difficult, and has not yet been attempted within the known literature. Nonetheless, several meta-analyses and systematic reviews have attempted to collate SRL findings by taking a strategy-by-strategy approach to categorisation, based on macro-level SRL constructs like metacognition and motivation (Richardson, Abraham \& Bond, 2012; Robbins et al., 2004; Sitzmann \& Ely, 2011). Garcia's (1995) description of 'skill' and 'will' related strategies has had considerable traction in this area; skill-related strategies correspond to learning tactics in the cognitive and metacognitive domains, whereas will-related strategies refer to a student's motivational orientation in terms of goals, values, and expectancies (Garcia, 1995). While the grouping of like-strategies has made the reporting and measurement of SRL more convenient, it is important to remain mindful of the fact that students do not engage in 'metacognition' or 'motivation' writ large. Rather, students both actively and autonomously deploy individual metacognitive and motivational strategies depending on the nature of the academic task and learning environment (Greene \& Azevedo, 2009).

\section{Metacognitive Strategies}

Skill-related, or metacognitive SRL strategies, have been found to correlate with academic performance in higher education (Tanner, 2012; Cohen, 2012; Bjork, Dunlosky \& Kornell, 2012), especially when applied over the duration of a learning task (Greene \& Azevedo, 2012). Metacognition is considered to be a necessary component of SRL, but is not by itself sufficient for SRL. Rather, SRL is one of many conceivable domains where metacognition - or "thinking about thinking" - can be applied. Metacognition of learning, or 'meta-learning', involves monitoring cognitive processes, and responding by selecting and implementing taskappropriate actions ("thinking about learning") (Wolters, 2003). Metacognition is often divided into 'monitoring' and 'control' strategies (Dinsmore et al., 2008). Most students monitor their learning (Colthorpe, Ogiji, Ainscough, Zimbardi, \& Anderson, 2019; Stanton, Neider, Gallegos, \& Clark, 2015), though to be considered 'metacognitive', students must then adapt their study regimes based on the information drawn from self-monitoring. The combined influence of metacognitive monitoring and control has been found to lead to a deeper conceptual understanding of the content, more efficient and targeted study, and an overall reduction in effortful learning (Greene, Moos, \& Azevedo 2011; Hartwig \& Dunlosky, 2012).

A core metacognitive monitoring strategy is the judgement of learning (JOL), or a selfevaluation of one's understanding of a particular topic (Table 1) (Nelson \& Dunlosky, 1991). Students who make JOLs tend to outperform those who do not evaluate their understanding, though this seems to depend on the quality of the JOL. Students who self-evaluate their learning based on subjective factors such as 'fluency' - or how easy it feels to learn something - tend 
to make JOLs that inaccurately represent their actual level of understanding (Koriat \& Ma'ayan, 2005). Fluency-driven JOLs, called ease-of-learning (EOL) judgements, lead students to focus on content that feels easy to retrieve from memory ('retrieval fluency'), or content that feels easy to study and comprehend ('encoding fluency'), raising the risk of premature study terminations and overconfidence (Table 1) (Alter \& Oppenheimer, 2009). Thus, JOLs are most effective when they are grounded in objective indicators of understanding, allowing for appropriate adjustments of attention and effort. For example, study tactics like self-testing (Hartwig \& Dunlosky, 2012) and spaced study (Kornell \& Bjork, 2008), are associated with high JOL accuracy and exam prediction accuracy, whereas passively re-reading material is not. There is, however, some evidence to suggest that EOL-based judgements while generally detrimental - constitute a useful tool for highly self-regulated learners. One study found that self-regulating students were more likely to adopt study practices with high initial confidence, but high risk of error (e.g., memorising material extensively prior to selftesting). In doing so, the negative experiences associated with making high-confidence errors allowed for encoding of stronger memories of the content (Butterfield \& Metcalfe, 2001).

\section{Motivational Strategies}

Ultimately, metacognition is driven by students' effort, which is mediated by underlying motivation, or 'will'. Motivation is typically described as either intrinsic (e.g., personal bests) or extrinsic (e.g., competition) (Vallerand \& Blssonnette, 1992). Intrinsic motivations tend to be more stable over time and across academic contexts than extrinsic motivations. As such, intrinsically motivated students tend to reap performance benefits; extrinsic motivations, on the other hand, do not (Pintrich, 2004). Importantly, intrinsic motivations form only part of the motivational profile of self-regulated students. The attributions students make about the causes of positive or negative exam results strongly impacts performance on subsequent assessments. For example, self-regulated learners tend to attribute academic failures to controllable factors, like an inadequate study regime, whereas unregulated students explain results in terms of fixed or absolute causes, like the quality of teaching, or the fairness of the exam (Table 2) (Robbins et al., 2004). In addition to motivation type and attributional style, students' self-efficacy - or their perceived level of academic competence - has been found to be one of the strongest predictors of performance in higher education (Richardson et al., 2012; Robbins et al., 2004). Thus, high-achieving students are often intrinsically driven toward success, all the while believing they have what it takes to achieve it. Evidence also seems to suggest that aiming for positive outcomes ('performance approach') - as opposed to wanting to avoid failure - is associated with improved performance. In fact, a 'performance avoidance' attitude towards assessment has been found to negatively correlate with performance, meaning students who are desperate to avoid underperforming end up with lower marks (Richardson et al., 2012).

Students' motivation is a key regulator of strategy use, persistence, effort, and performance. But can motivation itself be regulated? Regulation of motivation has been argued to be almost as essential as cognitive and metacognitive control (Pintrich, 2004). Self-efficacy, task perceptions, and interest in the subject matter can be monitored and controlled during learning (Wolters, 2003). As a prime example, self-regulators employ self-talk to direct themselves toward positive mindsets ("I know I can do this"), and away from negative mindsets brought on by test anxiety (“don't think about grades right now"). Self-regulated learners may even temporarily recruit extrinsic motivational factors to drive them through periods of high effort ("I'll reward myself if I get through this next section of study"). Thus, while intrinsic motivations are generally more effective than extrinsic motivations in driving effort and persistence, the targeted application of extrinsic factors may play a supplementary role in SRL. Similarly, performance avoidance attitudes, while generally detrimental to performance, can 
be applied discreetly to aid study practices. Some have suggested that briefly reminding oneself of the shame or regret that might follow from failing an exam constitutes an effective motivational SRL strategy (Pintrich, 2004). Self-regulated learners may even implement strategies to boost intrinsic motivation in the short-term, which often occurs when students feel disinterested or disengaged. They may do this by regularly raising the perceived value of academic tasks, thereby making it more relevant or useful to them (e.g., applying the content to real world scenarios) (Andrew, McVicar, Zanganeh, \& Henderson, 2015). Therefore, active self-regulation of both cognition (metacognition) and motivation, in a context-specific manner, constitutes an effective approach to learning in higher education.

\section{Self-Regulated Learning in Science}

It has been argued that the goal of a science education is to equip students with the tools to think like scientists (Tanner, 2012). In higher education, the natural sciences - comprised of life (i.e., biology) and physical (i.e., chemistry, physics, astronomy, earth sciences) sciences are typically taught in modules that, when integrated, make up complex systems. Students are expected to construct, modify, and replace their pre-existing conceptual structures, accounting for new phenomena where previous conceptions failed to do so. Thus, success in science is at least in part related to how students reconstruct their mental models (Schraw, Crippen, \& Hartley, 2006; Sebesta \& Bray Speth, 2017). As such, certain SRL strategies that are essential to science learning may not be as advantageous in other academic disciplines. In one self-report study that compared SRL across multiple disciplines, differences between the natural sciences and the humanities were found (Vanderstoep, Pintrich, \& Fagerlin, 1996). Exam scores in science courses were correlated with a greater quantity of metacognitive strategies, especially those strategies related to the organisation of knowledge. Interestingly, regulation of task value perceptions, self-efficacy, and intrinsic interest, were found to be a much stronger predictor of performance in the sciences than in the humanities. Follow-up research targeted to introductory courses in chemistry (Sandi-Urena, Cooper, \& Stevens, 2012), biology (Sebesta \& Bray-Speth, 2017) and physics (Deslauriers, Harris, Lane, \& Wieman, 2012) have shown support for the notion that metacognitively active science students are both proficient at identifying their own misconceptions, and willing to engage in unfamiliar forms of learning.

\section{Instructional Approaches}

Higher education science degrees aim to promote 'inquiry-based learning', whereby students are encouraged to generate research questions, propose solutions, and test results (Tanner, 2012; Boud \& Dochy, 2010). The purpose of inquiry-based learning is to assist students in the construction of a hierarchy of knowledge increasing in complexity, as opposed to merely accruing fact-based information. However, engaging in 'authentic' inquiry-based learning is a difficult skill to master. The extent to which inquiry is considered authentic largely depends upon whether students generate research questions and propose solutions independently, all the while maintaining an awareness of analytical and interpretive biases (Schraw et al., 2006). Authentic inquiry, therefore, is intimately linked with SRL. In one study, students were taught to employ metacognitive strategies in the context of an inquiry-based teaching module. By the end of the module, students more actively engaged in critical discussion, and were found to exhibit a deeper understanding of the scientific content (Seraphin, Philippoff, Kaupp, \& Vallin, 2012). There is also evidence that students develop metacognitive skills by engaging in reflective writing exercises during and after learning. In so doing, students are able to raise the quality and quantity of their self-evaluations (JOLs), and become more self-regulated in how they approach challenging scientific concepts (O'Loughlin \& Griffith, 2020). 
Table 1: A summarised list of metacognitive strategies giving details of their definitions and relationship with academic performance.

\begin{tabular}{|c|c|c|c|}
\hline Class & $\begin{array}{l}\text { Strategy } \\
\text { Definition }\end{array}$ & Measured variable & $\begin{array}{l}\text { Positively correlated with } \\
\text { achievement? } \\
\text { Reference }\end{array}$ \\
\hline \multirow[t]{3}{*}{$\begin{array}{l}\text { Metacognitive } \\
\text { Monitoring }\end{array}$} & \multirow{2}{*}{$\begin{array}{l}\text { Judgement of Learning (JOL): } \\
\text { Predictions about future assessment } \\
\text { performance based on currently recallable } \\
\text { items. }\end{array}$} & $\begin{array}{l}\text { Accuracy of predictions and } \\
\text { postdictions of exam results }\end{array}$ & $\begin{array}{l}\text { High Accuracy: Yes } \\
\text { Dunlosky \& Rawson, } 2012\end{array}$ \\
\hline & & $\begin{array}{l}\text { Accuracy of self-evaluations of } \\
\text { complexity of understanding }\end{array}$ & $\begin{array}{l}\text { High Accuracy: Yes } \\
\text { Kitsantas \& Zimmerman, } 2006\end{array}$ \\
\hline & $\begin{array}{l}\text { Ease of Learning Judgement (EOL): } \\
\text { Predictions about what will be easy to } \\
\text { learn, either in terms of which items will } \\
\text { be easiest or which will make learning } \\
\text { easiest. }\end{array}$ & $\begin{array}{l}\text { Encoding fluency; subjective feeling } \\
\text { that a piece of information is easy to } \\
\text { learn }\end{array}$ & $\begin{array}{l}\text { Variable } \\
\text { Koriat \& Ma'ayan, } 2005\end{array}$ \\
\hline \multirow[t]{2}{*}{$\begin{array}{l}\text { Metacognitive } \\
\text { Control }\end{array}$} & $\begin{array}{l}\text { Spaced study: } \\
\text { Studying several topics by introducing } \\
\text { breaks between like items. }\end{array}$ & Self-report, direct observation & $\begin{array}{l}\text { Yes } \\
\text { Kornell \& Bjork, } 2008\end{array}$ \\
\hline & Self-testing: Study using tests and quizzes & Self-report, direct observation & $\begin{array}{l}\text { Yes } \\
\text { Hartwig \& Dunlosky, } 2012\end{array}$ \\
\hline
\end{tabular}


Table 2: A summarised list of motivational strategies giving details of their definitions and relationship with academic performance.

\begin{tabular}{|c|c|c|c|}
\hline Class & $\begin{array}{l}\text { Strategy } \\
\text { Definition }\end{array}$ & Sample & $\begin{array}{l}\text { Positively correlated with achievement? } \\
\text { Reference }\end{array}$ \\
\hline \multirow[t]{2}{*}{$\begin{array}{l}\text { Academic } \\
\text { motivation }\end{array}$} & $\begin{array}{l}\text { Intrinsic: } \\
\text { Self-motivation for and enjoyment of } \\
\text { academic learning and tasks }\end{array}$ & $\begin{array}{l}\text { "I find it fun and generally enjoy } \\
\text { learning, especially when directed } \\
\text { toward a goal" }\end{array}$ & $\begin{array}{l}\text { Yes } \\
\text { Pintrich, } 2004\end{array}$ \\
\hline & $\begin{array}{l}\text { Extrinsic: } \\
\text { Learning and involvement in academic } \\
\text { tasks for instrumental reasons }\end{array}$ & $\begin{array}{l}\text { "I study hard because I am a highly } \\
\text { competitive person" }\end{array}$ & $\begin{array}{l}\text { No } \\
\text { Pintrich, } 2004\end{array}$ \\
\hline \multirow[t]{2}{*}{$\begin{array}{l}\text { Outcome } \\
\text { expectancies }\end{array}$} & $\begin{array}{l}\text { Pessimistic: } \\
\text { Characterised by internal, stable (fixed) } \\
\text { attributions about the academic } \\
\text { outcomes, reflecting low perceived } \\
\text { academic control }\end{array}$ & "I'm not smart enough to pass the exam" & $\begin{array}{l}\text { No } \\
\text { Richardson et al., } 2012\end{array}$ \\
\hline & $\begin{array}{l}\text { Optimistic: } \\
\text { Characterised by external, global } \\
\text { (changeable) attributions about academic } \\
\text { outcomes, reflecting high perceived } \\
\text { academic control }\end{array}$ & "Studying hard will lead to good grades" & $\begin{array}{l}\text { Yes } \\
\text { Richardson et al., } 2012\end{array}$ \\
\hline \multirow[t]{2}{*}{$\begin{array}{l}\text { Goal- } \\
\text { orientation }\end{array}$} & $\begin{array}{l}\text { Performance avoidance: } \\
\text { Anticipation of negative achievement }\end{array}$ & $\begin{array}{l}\text { "My fear of failing motivates me to } \\
\text { work hard" }\end{array}$ & $\begin{array}{l}\text { No } \\
\text { Richardson et al., } 2012\end{array}$ \\
\hline & $\begin{array}{l}\text { Performance approach: } \\
\text { Anticipation of positive achievement }\end{array}$ & $\begin{array}{l}\text { "I want to score highly on the final } \\
\text { exam" }\end{array}$ & $\begin{array}{l}\text { Yes } \\
\text { Richardson et al., } 2012\end{array}$ \\
\hline
\end{tabular}


Importantly, interventions that aim to raise metacognitive skill in the science classroom are not universally effective. One study in undergraduate physiology students investigated inquirybased learning in the context of student collaboration. The authors found no significant difference between collaborative learning and control groups in their SRL, nor any meaningful differences in final grade (Landon et al., 2019). While this finding seems to support a negative correlation between collaboration and self-regulation in the context of inquiry-based learning, there is evidence to suggest that the type of collaboration may be important. When students are paired peer-to-peer by level of achievement, for example, they have been found to make stronger metacognitive gains during inquiry-based tasks than when placed in student-teacher pairings (Schraw et al., 2006). Facilitating comfortable discussions about misconceptions, therefore, may help students identify gaps in their understanding, and boost academic selfefficacy by making students aware that misconceptions are common (Sen \& Yilmaz, 2012). In fact, students with lower prior scientific knowledge - who are often predisposed to misconceptions - seem to reap greater benefits from metacognitive interventions. One study in undergraduate chemistry found that an inquiry-based learning exercise promoted metacognition in students with a weak science background, but not in those with a strong science background (Tosun \& Senocak, 2013). This trend of disproportionate benefit has also been observed in food science (Gezer-Templeton et al., 2017) and biology (Dang et al., 2018) students, suggesting a potential 'ceiling effect' of metacognitive interventions in adept selfregulators (Haak, HilleRisLambers, Pitre, \& Freeman, 2011).

\section{Beliefs \& Epistemologies}

Students' attitudes toward learning are strongly influenced by their beliefs about the nature of scientific knowledge (Schraw et al., 2006). When students enter higher education, they typically hold 'realist' conceptions about knowledge, viewing it as information that is simple, fixed, and teachable. In science, students are also markedly more realist-orientated in comparison to humanities students (Jehng, Johnson, \& Anderson, 1993). This is significant, as realist attitudes have been found to negatively impact student learning in a number of ways. Notably, realist students are less likely to participate in collaborative learning (SchommerAikins, 2002), are biased towards essential material ("will this be on the test?"), and employ fewer SRL strategies overall (Markwell \& Courtney, 2006). In contrast, students who appreciate the malleability of science are more likely to initiate shifts in their mental models (Greene, Hutchison, Costa, \& Crompton, 2012), engage in critical thinking and problem solving, and score highly on assessments (Schommer-Aikins, 2002). Since achievement in science is related to the integration of concepts from modules of information, an openness to conceptual change is essential to attaining a robust understanding of a complex topic. Considering mental models, students who appreciate the flexibility of scientific knowledge are thought to be better able to manage the cognitive disequilibrium associated with conceptual change (Seraphin et al., 2012). Students who are more advanced in their science education tend to hold more evolved epistemologies, or how they conceptualize the limits and development of knowledge. Since classroom environments in the later stages of a science degree are typically less didactic, students may need to develop their own ideas and arguments such that they are able to defend them in complex classroom discussions.

\section{Development of Self-Regulated Learning in Undergraduates}

Introductory students have been found to be less self-regulated in their learning than seniorlevel students (Stanton et al., 2019). Many students do not self-regulate their learning in high school, and struggle to adapt to the independent learning environment of higher education (Dye \& Stanton, 2017). Thus, researchers are beginning to pay more attention to how students develop SRL as they progress through their degrees. Studies have shown that third-year 
students are more aware of the benefits associated with self-regulation, and with the mechanisms of the learning process in a general sense, than first-year students (Stanton et al., 2019). While first and third-year students seem to demonstrate similar competence in their evaluations of effective and ineffective study strategies, third-years are more likely to consider why a strategy might have been effective, and are less biased against self-implicating explanations ("I didn't use the strategy properly") (Stanton et al., 2019). Once ineffective strategies have been identified, third-years tend to adjust or modify their original strategies, whereas first year students outright reject them in favour of new approaches (Stanton et al., 2015). This preference for study regime adjustment among experienced students may be related to how their perceptions of the benefits of study strategies change over time (Dye \& Stanton, 2017). For example, first-years report that study strategies, such as collaboration, are useful insofar as they provide an opportunity to compare answers to practice questions in preparation for the exam. On the other hand, third-years are more likely to recognise collaboration as a way of exposing gaps in their understanding and uncovering misconceptions (Stanton et al., 2019). At the same time, third-year students seem to be more optimistic in their outcome expectancies for assessments, attributing poor results to controllable (i.e., inadequate study) rather than fixed (i.e. innate ability) factors (Perry et al., 2005). Thus, students not only become more selfregulated in how they perceive and utilise study strategies, but also in how they appraise academic outcomes. On the whole, students' control over their learning, both actual and perceived, increases as they progress through higher education.

\section{Self-Regulated Learning in the Biosciences}

Specific trends in SRL within science disciplines have yet to emerge due to lack of targeted research in this area. Although SRL has been extensively studied in the context of learning bioscience, few studies have focused on identifying differences between the biosciences and other science disciplines; studies by Vanderstoep et al. (1996) and Virtanen \& Nevgi (2010) are among the few. 'Bioscience' is being used to refer to subjects such as anatomy, physiology and biochemistry that appeal to fundamental concepts in chemistry and physics. Virtanen and Nevgi (2010) found that bioscience students had lower expectations of success and higher test anxiety than students in technology and behavioural science degrees. Bioscience students also ranked lowest on measures of time-management and self-awareness, which the authors suggest may be related to the teaching style. They hypothesise that because the integration of facts into a hierarchical structure of knowledge is so heavily teacher-regulated in the early phases of bioscience studies, SRL becomes a less essential tool (Virtanen \& Nevgi, 2010). If true, the question of whether bioscience students graduate as independent and fully self-regulated learners is made especially interesting. While there is little doubt SRL is still practiced by bioscience students (Colthorpe et al., 2019; Stanton et al., 2019), and that self-regulated students perform highly in assessments (Sebesta \& Bray Speth, 2017), further research is needed to investigate how teacher-regulated learning effects the development of SRL.

There is a growing literature on the value of SRL in core foundation bioscience subjects taken by students in vocational courses, such as nursing, pharmacy, and allied health. For these students, motivational and metacognitive SRL strategies have been found to be exceptionally important to academic achievement (Andrew et al., 2015). There is some evidence to suggest that this may be due to vocational science students exhibiting lower SRL than students in science degrees without a discreet vocational focus (e.g., Bachelor of Science). This is thought to be related to vocational students having to master bioscience material outside their area of expertise or interest (Whyte, Madigan, \& Drinkwater, 2011). In addition to being less selfregulated in their learning of bioscience material (Friedel \& Treagust, 2005), vocational students have been found to struggle learning bioscience material, in what researchers have 
termed the 'bioscience problem' (c.f. Rathner \& Byrne, 2014). The bioscience problem is a form of science aversion, representative of students who may perceive science as having little to no relevance to them ("I don't need science"), or who exhibit low science self-efficacy ("I don't have a scientific mind"). As such, it is noteworthy that students who start the semester with high self-efficacy have been found to outperform their peers on end-of-semester exams (Andrew, 1998).

The impact of SRL on academic outcomes in foundation bioscience subjects has sparked an interest in the design and implementation of SRL interventions (McVicar et al., 2014). The challenge for teaching instructors lies in finding ways to effectively mitigate science anxiety, often brought on by confusing terminology and intense time-commitments, while simultaneously raising scientific interest, and a sense that science holds more relevance to students' future careers. Positive findings from studies from multiple science disciplines suggest that there are a number of ways in which this can be achieved. One study that monitored science self-efficacy and science anxiety over a single semester found that students who increased in science self-efficacy emphasised the importance of finding ways to relate science material to their everyday lives (McBride et al., 2019). In a study by Rathner \& Byrne (2014), nursing students enrolled in a first-year physiology subject who participated in regular collaborative learning exercises outperformed their peers. Collaborative learning exercises are effective at exposing students' misconceptions; an experience that can often be reassuring as students discover that their misunderstandings are shared by others. Even in a traditional lecture-based setting, Efstathiou \& Bailey (2012) were able to show that a live audience response technology raised nursing students' awareness of the adequacy of their level of scientific knowledge and understanding - a key feature in the development of effective metacognitive monitoring and control strategies.

\section{Conclusion}

Research related to the benefits of SRL is of great importance to the teaching of effective learning, curricula design, and higher education more broadly. While aspects of the conceptual structure of SRL remain disputed, there is a consensus in the literature that self-regulated leaners employ various metacognitive and motivational strategies that allow them to optimise their learning. The degree to which students metacognitively monitor and control their learning has been found to directly impact how they self-evaluate and subsequently modify their study regimes. The motivational state of the student acts as a driver of SRL strategy use, as well as more general attitudes towards learning and achievement. In science courses, subject demands typically necessitate the use of particular SRL strategies in order to overcome academic challenges. Inquiry-based questioning is more quickly mastered by self-regulated students who often employ reflective writing exercises to optimise conceptual transitions and boost the accuracy of their self-evaluations. These practices tend to develop over time in undergraduates as students begin to better appreciate the malleability of scientific knowledge early on, and engage in study exercises that promote learning and achievement. Although the specific advantages afforded to bioscience students who employ SRL strategies are yet to be determined, there appears to be a relationship between perceptions of both academic control and task relevance to future academic success.

\section{References}

Alter, A. L., \& Oppenheimer, D. M. (2009). Uniting the Tribes of Fluency to Form a Metacognitive Nation.

Personality and Social Psychology Review, 13(3), 219-235. 
Andrew, S., McVicar, A., Zanganeh, M., \& Henderson, N. (2015). Self-efficacy and relevance of bioscience for nursing, midwifery and healthcare students. Journal of clinical nursing, 24(19-20), 2965-2972.

Australian Qualifications Framework (2013). Australian qualifications framework. Australian Qualifications Framework Council, 63.

Bandura, A. (1986). Social foundations of thought and action: A social cognitive theory. Englewood Cliffs, NJ, US.

Bjork, R., Dunlosky, J., \& Kornell, N. (2012). Self-Regulated Learning: Beliefs, Techniques, and Illusions. Annual Review of Psychology, 64.

Boud, D., \& Dochy, F. (2010). Assessment 2020. Seven propositions for assessment reform in higher education.

Butterfield, B., \& Metcalfe, J. (2001). Errors committed with high confidence are hypercorrected. Journal of Experimental Psychology: Learning, Memory, and Cognition, 27(6), 1491.

Colthorpe, K., Ogiji, J., Ainscough, L., Zimbardi, K., \& Anderson, S. (2019). Effect of Metacognitive Prompts on Undergraduate Pharmacy Students' Self-regulated Learning Behavior. American Journal of Pharmaceutical Education, 83(4).

Cohen, M. (2012). The importance of self-regulation for college student learning. College Student Journal, 46(4), 892-902.

Dang, N. V., Chiang, J. C., Brown, H. M., \& McDonald, K. K. (2018). Curricular activities that promote metacognitive skills impact lower-performing students in an introductory biology course. Journal of microbiology \& biology education, 19(1).

Deslauriers, L., Harris, S., Lane, E., \& Wieman, C. (2012). Transforming the lowest-performing students: an intervention that worked.

Dinsmore, D., Alexander, P., \& Loughlin, S. (2008). Focusing the Conceptual Lens on Metacognition, Selfregulation, and Self-regulated Learning. Educational Psychology Review, 20, 391-409.

Dunlosky, J., \& Bjork, R. A. (2008). The integrated nature of metamemory and memory. In Handbook of metamemory and memory. (pp. 11-28). New York, NY, US: Psychology Press.

Rawson, K. A., \& Dunlosky, J. (2011). Optimizing schedules of retrieval practice for durable and efficient learning: How much is enough?. Journal of Experimental Psychology: General, 140(3), 283.

Dye, K. M., \& Stanton, J. D. (2017). Metacognition in upper-division biology students: Awareness does not always lead to control. CBE-Life Sciences Education, 16(2).

Efstathiou, N., \& Bailey, C. (2012). Promoting active learning using Audience Response System in large bioscience classes. Nurse Education Today, 32(1), 91-95.

Friedel, J. M., \& Treagust, D. F. (2005). Learning bioscience in nursing education: perceptions of the intended and the prescribed curriculum. Learning in Health and Social Care, 4(4), 203-216.

Garcia, T. (1995). The role of motivational strategies in self-regulated learning. New directions for teaching and learning, 29-29

Gezer-Templeton, P. G., Mayhew, E. J., Korte, D. S., \& Schmidt, S. J. (2017). Use of exam wrappers to enhance students' metacognitive skills in a large introductory food science and human nutrition course. Journal of Food Science Education, 16(1), 28-36.

Greene, J., Moos, D., \& Azevedo, R. (2011). Self-regulation of learning with computer-based learning environments. New directions for teaching and learning.

Greene, J. A., \& Azevedo, R. (2009). A macro-level analysis of SRL processes and their relations to the acquisition of a sophisticated mental model of a complex system. Contemporary Educational Psychology, 34(1), 18-29.

Greene, J. A., Hutchison, L. A., Costa, L. J., \& Crompton, H. (2012). Investigating how college students' task definitions and plans relate to self-regulated learning processing and understanding of a complex science topic. Contemporary Educational Psychology, 37(4), 307-320.

Haak, D. C., HilleRisLambers, J., Pitre, E., \& Freeman, S. (2011). Increased Structure and Active Learning Reduce the Achievement Gap in Introductory Biology. Science, 332(6034), 1213.

Hartwig, M. K., \& Dunlosky, J. (2012). Study strategies of college students: are self-testing and scheduling related to achievement? Psychonomic Bulletin and Review, 19(1), 126-134.

Jehng, J. C. J., Johnson, S. D., \& Anderson, R. C. (1993). Schooling and students' epistemological beliefs about learning. Contemporary Educational Psychology, 18(1), 23-35.

Koriat, A., \& Ma'ayan, H. (2005). The effects of encoding fluency and retrieval fluency on judgments of learning. Journal of Memory and Language, 52(4), 478-492.

Kornell, N., \& Bjork, R. A. (2008). Learning concepts and categories: Is spacing the "enemy of induction"?. Psychological Science, 19(6), 585-592.

Kitsantas, A., \& Zimmerman, B. J. (2006). Enhancing self-regulation of practice: The influence of graphing and self-evaluative standards. Metacognition and Learning, 1(3), 201-212.

Kornell, N., \& Bjork, R. A. (2008). Learning concepts and categories: Is spacing the "enemy of induction"?. Psychological Science, 19(6), 585-592. 
Langdon, J., Botnaru, D. T., Wittenberg, M., Riggs, A. J., Mutchler, J., Syno, M., \& Caciula, M. C. (2019). Examining the effects of different teaching strategies on metacognition and academic performance. Advances in physiology education, 43(3), 414-422.

Markwell, J., \& Courtney, S. (2006). Cognitive development and the complexities of the undergraduate learner in science classroom. Biochemistry and molecular biology education : a bimonthly publication of the International Union of Biochemistry and Molecular Biology, 34, 267-271.

McBride, E., Oswald, W. W., Beck, L. A., \& Vashlishan Murray, A. (2020). "I'm just not that great at science": Science self-efficacy in arts and communication students. Journal of Research in Science Teaching, 57(4), 597-622.

McVicar, A., Andrew, S., \& Kemble, R. (2014). Biosciences within the pre-registration (pre-requisite) curriculum: An integrative literature review of curriculum interventions 1990-2012. Nurse Education Today, 34(4), 560-568.

Miller, G. A., Galanter, E., \& Pribram, K. H. (1960). Plans and the structure of behavior. NY: Henry Holt and Co.

Nelson, T. O., \& Dunlosky, J. (1991). When people's judgments of learning (JOLs) are extremely accurate at predicting subsequent recall: The "delayed-JOL effect.". Psychological Science, 2(4), 267-270.

Oliver, B., \& Jorre de St Jorre, T. (2018). Graduate attributes for 2020 and beyond: Recommendations for Australian higher education providers. Higher Education Research \& Development, 37(4), 821-836.

Panadero, E. (2017). A Review of Self-regulated Learning: Six Models and Four Directions for Research. Frontiers in Psychology, 8, 422-422.

Perry, R. P., Hladkyj, S., Pekrun, R. H., Clifton, R. A., \& Chipperfield, J. G. (2005). Perceived Academic Control and Failure in College students: A Three-Year Study of Scholastic Attainment. Research in Higher Education, 46(5), 535-569.

Pilcher, S., \& Torii, K. (2018). Crunching the number: Exploring the use and usefulness of the Australian Tertiary Admission Rank (ATAR).

Pintrich, P. R., \& De Groot, E. V. (1990). Motivational and self-regulated learning components of classroom academic performance. Journal of Educational Psychology, 82(1), 33.

Pintrich, P. R. (2000). The role of goal orientation in self-regulated learning. In Handbook of self-regulation. (pp. 451-502). San Diego, CA, US: Academic Press.

Pintrich, P. R. (2000). The role of goal orientation in self-regulated learning. In Handbook of self-regulation (pp. 451-502). Academic Press.

Pintrich, P. R. (2004). A conceptual framework for assessing motivation and self-regulated learning in college students. Educational psychology review, 16(4), 385-407.

Puustinen, M., \& Pulkkinen, L. (2001). Models of Self-regulated Learning: A review. Scandinavian Journal of Educational Research, 45(3), 269-286.

Rathner, J. A., \& Byrne, G. (2014). The use of team-based, guided inquiry learning to overcome educational disadvantages in learning human physiology: a structural equation model. Advances in Physiology Education, 38(3), 221-228.

Richardson, M., Abraham, C., \& Bond, R. (2012). Psychological correlates of university students' academic performance: a systematic review and meta-analysis. Psychological Bulletin, 138(2), 353-387.

Robbins, S. B., Lauver, K., Le, H., Davis, D., Langley, R., \& Carlstrom, A. (2004). Do psychosocial and study skill factors predict college outcomes? A meta-analysis. Psychological Bulletin, 130(2), 261.

Roth, A., Ogrin, S., \& Schmitz, B. (2016). Assessing self-regulated learning in higher education: a systematic literature review of self-report instruments. Educational Assessment, Evaluation and Accountability, 28(3), 225-250.

Rovers, S. F. E., Clarebout, G., Savelberg, H. H. C. M., de Bruin, A. B. H., \& van Merriënboer, J. J. G. (2019). Granularity matters: comparing different ways of measuring self-regulated learning. Metacognition and Learning, 14(1), 1-19.

Ruban, L., McCoach, D. B., McGuire, J., \& Reis, S. (2003). The Differential Impact of Academic SelfRegulatory Methods on Academic Achievement Among University Students With and Without Learning Disabilities. Journal of Learning Disabilities, 36, 270-286.

Sandi-Urena, S., Cooper, M., \& Stevens, R. (2012). Effect of cooperative problem-based lab instruction on metacognition and problem-solving skills. Journal of Chemical Education, 89(6), 700-706.

Schellings, G., \& Van Hout-Wolters, B. (2011). Measuring strategy use with self-report instruments: Theoretical and empirical considerations. Metacognition and Learning, 6(2), 83-90.

Schommer-Aikins, M. (2002). Epistemological belief system. Personal epistemology: The psychology of beliefs about knowledge and knowing, 105-118.

Schraw, G., Crippen, K. J., \& Hartley, K. (2006). Promoting Self-Regulation in Science Education: Metacognition as Part of a Broader Perspective on Learning. Research in Science Education, 36(1), 111-139. 
Sebesta, A. J., \& Bray Speth, E. (2017). How Should I Study for the Exam? Self-Regulated Learning Strategies and Achievement in Introductory Biology. CBE - Life Sciences Education, 16(2).

Seraphin, K., Philippoff, J., Kaupp, L., \& Vallin, L. (2012). Metacognition As Means to Increase the Effectiveness of Inquiry-based Science Education. Science Education International, 22, 366-382.

Sitzmann, T., \& Ely, K. (2011). A meta-analysis of self-regulated learning in work-related training and educational attainment: what we know and where we need to go. Psychological Bulletin, 137(3), 421-442.

Stanton, J. D., Dye, K. M., \& Johnson, M. (2019). Knowledge of Learning Makes a Difference: A Comparison of Metacognition in Introductory and Senior-Level Biology Students. CBE-Life Sciences Education, 18(2), 24.

Stanton, J. D., Neider, X. N., Gallegos, I. J., \& Clark, N. C. (2015). Differences in Metacognitive Regulation in Introductory Biology Students: When Prompts Are Not Enough. CBE - Life Sciences Education, 14(2).

Tanner, K. D. (2012). Promoting Student Metacognition. CBE_Life Sciences Education, 11(2), 113-120.

Tosun, C., \& Senocak, E. (2013). The effects of problem-based learning on metacognitive awareness and attitudes toward chemistry of prospective teachers with different academic backgrounds. Australian Journal of Teacher Education, 38(3), 4.

Vallerand, R. J., \& Blssonnette, R. (1992). Intrinsic, extrinsic, and amotivational styles as predictors of behavior: A prospective study. Journal of Personality, 60(3), 599-620.

Vanderstoep, S. W., Pintrich, P. R., \& Fagerlin, A. (1996). Disciplinary Differences in Self-Regulated Learning in College Students. Contemporary Educational Psychology, 21(4), 345-362.

Virtanen, P., \& Nevgi, A. (2010). Disciplinary and gender differences among higher education students in selfregulated learning strategies. Educational Psychology, 30(3), 323-347.

Whyte, D. G., Madigan, V., \& Drinkwater, E. J. (2011). Predictors of academic performance of nursing and paramedic students in first year bioscience. Nurse Education Today, 31(8), 849-854.

Winne, P., \& Perry, N. (2012). Measuring Self-Regulated Learning. Handbook of Self-regulation.

Winne, P. H., \& Hadwin, A. F. (1998). Studying as self-regulated learning. In Metacognition in educational theory and practice. (pp. 277-304). Mahwah, NJ, US: Lawrence Erlbaum Associates Publishers.

Wolters, C. A. (2003). Understanding procrastination from a self-regulated learning perspective. Journal of Educational Psychology, 95(1), 179-187.

Zimmerman, B. J. (2000). Attaining self-regulation: A social cognitive perspective. In Handbook of selfregulation. (pp. 13-39). San Diego, CA, US: Academic Press.

Zimmerman, B. J. (2001). Theories of self-regulated learning and academic achievement: An overview and analysis. 